\title{
An agent-based model to support community forest management and non-timber forest product harvesting in northern Thailand
}

\author{
Wuthiwong Wimolsakcharoen ${ }^{1,2}$, Pongchai Dumrongrojwatthana ${ }^{2 *}$, Christophe Le Page ${ }^{3,4}$, François Bousquet ${ }^{3,4}$, \\ Guy Trébuil ${ }^{5,6}$ \\ ${ }^{1}$ Biological Sciences Program, Faculty of Science, Chulalongkorn University, Bangkok, Thailand \\ ${ }^{2}$ Department of Biology, Faculty of Science, Chulalongkorn University, Bangkok, Thailand \\ ${ }^{3}$ CIRAD, UMR SENS, Montpellier, France \\ ${ }^{4}$ SENS, Univ. Montpellier, CIRAD, IRD, Univ. Paul Valéry, Montpellier, France \\ ${ }^{5}$ CIRAD, UMR Innovation, Montpellier, France \\ ${ }^{6}$ Innovation, Univ. Montpellier, CIRAD, INRAE, Montpellier SupAgro, Montpellier, France
}

\begin{abstract}
Agent-based models are popular in common-pool resource management to represent complex systems and stimulate collective action and management, where they are used to evaluate scenarios of stakeholders' choice in participatory simulations. We developed the "CoComForest" (COllaborative COMmunity FOREST management) model to support community forest management (CFM) and non-timber forest product (NTFP) harvesting in Nan Province, northern Thailand. The model was used as a computer-based role-playing game to support sharing of perceptions and knowledge among stakeholders, and in participatory simulations to explore future CFM scenarios. The Unified Modelling Language was used to build the conceptual model, subsequently implemented under the CORMAS (COmmon-pool Resource and Multi-Agent System) simulation platform. Several tests were conducted in the laboratory for verification and calibration before using this tool with 21 diverse stakeholders during a field workshop. Three different participatory gaming and simulation sessions were organized. The first one focused on the co-validation of the model with participants. They accepted most of the model functionalities and the scheduling of the rounds of play. The model was used in the subsequent two sessions to simulate the scenarios of firebreak establishment and introduction of outsiders intensively harvesting NTFPs, respectively. The results showed that the intensive harvesting practices of outsiders accelerated the depletion of resources, whereas the prevention of wildfire by establishing firebreaks could increase the resource availability in the landscape. The debriefing session at the end of the workshop focused on the analysis of simulation results and the relationships between the players' decision-making and their actual circumstances. Individual in-depth interviews conducted after the workshop helped to evaluate the use of this model with local stakeholders. Most participants considered the model as a useful common representation of the system they manage collectively. Its use in participatory simulations facilitated communication among the stakeholders searching for an adapted and acceptable collective action plan to improve CFM at the sub-district level in order to prevent the overharvesting of NTFPs by outsiders.
\end{abstract}

\section{Keywords}

participatory agent-based simulation; computer-assisted role-playing game; Companion Modelling (ComMod); CORMAS; knowledge exchange; Thailand

Correspondence:
Contact P. Dumrongrojwatthana at $\underline{\text { dpongchai@hotmail.com }}$

Cite this article as:

Wimolsakcharoen, W., Dumrongrojwatthana, P., Le Page, C., Bousquet, F., \& Trébuil, G.

An agent-based model to support community forest management and non-timber forest product harvesting in northern Thailand

Socio-Environmental Systems Modelling, vol. 3, 17894, 2021, doi:10.18174/sesmo.2020a17894

This work is licensed under a Creative Commons Attribution-NonCommercial 4.0 International License. 
Code availability

The CoComforest model was developed using the CORMAS modelling and simulation platform (Bousquet et al., 1998; Bommel et al., 2016). The model code and related data are publicly available at https://www.comses.net/codebases/abdcbbd1-6b95-4d7a-848e-f2bcb52d02a9/releases/1.0.0/.

\section{Introduction}

Community forestry generally provides active protection of a forest ecosystem and a regulation of its use by a community (Nayak \& Berkes, 2008). Composed of multiple subsystems, including ecological and social components interacting at multiple levels, it can be seen as a complex social-ecological system (SES) where ecological processes and human activities are interdependent, co-evolve, and are linked through various interactions and interconnections (Ostrom, 2009; Folke et al., 2010). In several regions of the world, including Thailand, community forests provide a great diversity of natural resources to local people who live in or near them (Salam et al., 2006). These resources are often utilized by multiple users with different viewpoints and pursuing specific objectives. Numerous and diverse interactions exist among these various types of users (or actors), as well as between them and their common environment (Gauli \& Hauser, 2009; Wimolsakcharoen et al., 2020).

A multi-agent system (MAS) approach is a metaphor of the social and biophysical dimensions of reality that consider a SES as a set of interacting autonomous entities located within a given environment (Drogoul \& Ferber, 1994). Such a representation is commonly used in ecosystem management. An agent-based model (ABM) is a key tool used to represent the diverse components and their interactions in a complex SES (Schulze et al., 2017). An ABM represents a set of interacting (often heterogeneous) agents who implement their tasks in a common environment, based on their specific objectives and available resources (Bousquet \& Le Page, 2004; Gleizes et al., 2011). In recent years, ABMs have become popular in several fields, particularly in ecology and commonpool resource management, especially to build a shared and understandable representation by the stakeholders of complex SESs. In addition, ABMs can be used to run simulations in order to identify, evaluate, and discuss the outcomes of desired resource management scenarios proposed by the researchers or the concerned stakeholders (Étienne et al., 2003; Bah et al., 2006).

The relevance of agent-based modelling to investigate land-use changes in SESs, where the forest represents a key land cover has been demonstrated through previous case studies (Le at al., 2008; Sun and Müller, 2013; Villamor et al., 2014). On the other hand, agent-based modelling has been used in community common-pool resource management to deal with various kinds of resources, such as water (Wise \& Crooks, 2012) and fisheries (Berman et al., 2004). However, its application to forest resources has been limited so far (Van Noordwijk, 2002; Purmono \& Guizol, 2006; Campo et al., 2009; Simon \& Étienne, 2010), especially to facilitate knowledge exchange among stakeholders and to promote the collective design of a community forest management (CFM) action plan. Using this approach to simulate a SES across institutional scales, such as scaling-up a CFM from the village level to a higher administrative one, is challenging because of the difficulties with (i) dealing with different institutions and diverse interests, (ii) managing such a participatory process involving heterogeneous participants and unequal power relations, and (iii) engaging managers of organizations with limited time to participate (Lippe et al., 2019).

In the family of participatory modelling and simulation approaches, Companion Modelling (ComMod) postulates that $A B M s$ can support social learning by providing a boundary object or negotiating artifact that allows stakeholders to deliberate through a multi-interpretable, consistent, transparent, and verifiable representation of reality (Van Bruggen et al., 2019). This process is composed of several successive, iterative but evolving, sequences of activities carried out with heterogeneous stakeholders to examine a given common resource management problem, and stimulate collective decision-making (Barreteau et al., 2003a). The ComMod activities aim at understanding a complex SES issue and strengthening the adaptive capacity of resource managers by generating a shared representation of the problem through the exchanges of knowledge, experiences, perceptions, and opinions among the concerned stakeholders, facilitated by modelling and simulation tools co-designed with them (Étienne, 2014). The model corresponding to this shared representation can then simulate the desired future scenarios selected by the local stakeholders to facilitate negotiation, the emergence of acceptable coordinating mechanisms, and agreed upon action plans. Accordingly, ComMod has 
been applied to foster collective learning. The ComMod activities frequently rely on the synergistic effects of a role-playing game (RPG) and an ABM (Bousquet et al., 2002). Such participatory modelling and simulation processes have been implemented in several regions of Thailand, particularly in the northern upland areas, to improve the management of irrigation water at the catchment scale (Promburom \& Bommel, 2005), to mitigate the risk of land degradation (Barnaud et al., 2007), and to mediate a land-use conflict between herders and foresters (Dumrongrojwatthana et al., 2011). It has also been deployed to facilitate the negotiation between a recently established national park and villagers harvesting non-timber forest products (NTFPs) (Ruankaew et al., 2010).

Taking stock of these case studies, we carried out a ComMod process with the focus on CFM with the objectives to (i) develop an ABM representing NTFP dynamics and agent harvesting behaviour; (ii) implement this model as a computer-based RPG (CRPG) for exploring the desired CFM scenarios identified by the NTFP harvesters and community forest managers. For this, we engaged with stakeholders from different villages in order to promote knowledge exchange and collaborative management of the community forests at the sub-district level in northern Thailand.

Following a description of the study site and methodology (Section 2), the model is described (Section 3). Then the proceedings and outcomes of the participatory gaming and simulation sessions held during a field workshop are presented (Section 4), followed by the analysis of the learning effects from using the model with local stakeholders. The article ends with a discussion covering the assessment of stakeholder participation, the factors linked to social learning, and the linkage between RPGs and ABMs. Finally, perspectives to translate the suggested management plans into actual collective actions are proposed.

\section{Materials and methods}

\subsection{Study site}

This case study was conducted in Lainan Sub-district, Wiang Sa District, Nan Province, northern Thailand (Figure 1), an area covering $125 \mathrm{~km}^{2}$ and containing different types of community forests around the seven villages of the sub-district that were officially founded almost half a century ago. According to Nantasen et al. (2005) and Wimolsakcharoen et al. (2020), three main periods can be distinguished in the evolution of community forestry at this site as follows:

(i) 1968-1975: Forest conservation activities. Forests were conserved for the two main purposes of protecting the remaining forest areas from deforestation due to the 1963 government policy on logging concessions, and from cattle grazing.

(ii) 1976-1995: Official establishment of community forests. Community forests in all villages of the sub-district were officially established and their boundaries delineated. Commanding rules and regulations for logging prohibition were introduced, and local management committees were set up.

(iii) Since 1996: Forest rehabilitation. As deforestation still occurred during the previous two periods, logging in community forests was strictly prohibited in all the villages.

The forest areas of almost all the villages in nearby sub-districts have been markedly degraded during the last few decades and Lainan's remaining community forests are still vulnerable to deforestation. This is the reason why this study site was selected for this research.

Currently, each village has its own independent CFM committee, enforcing different CFM rules and regulations, as shown in Table 1. The membership of these CFM committees is dominated by male village leaders. 

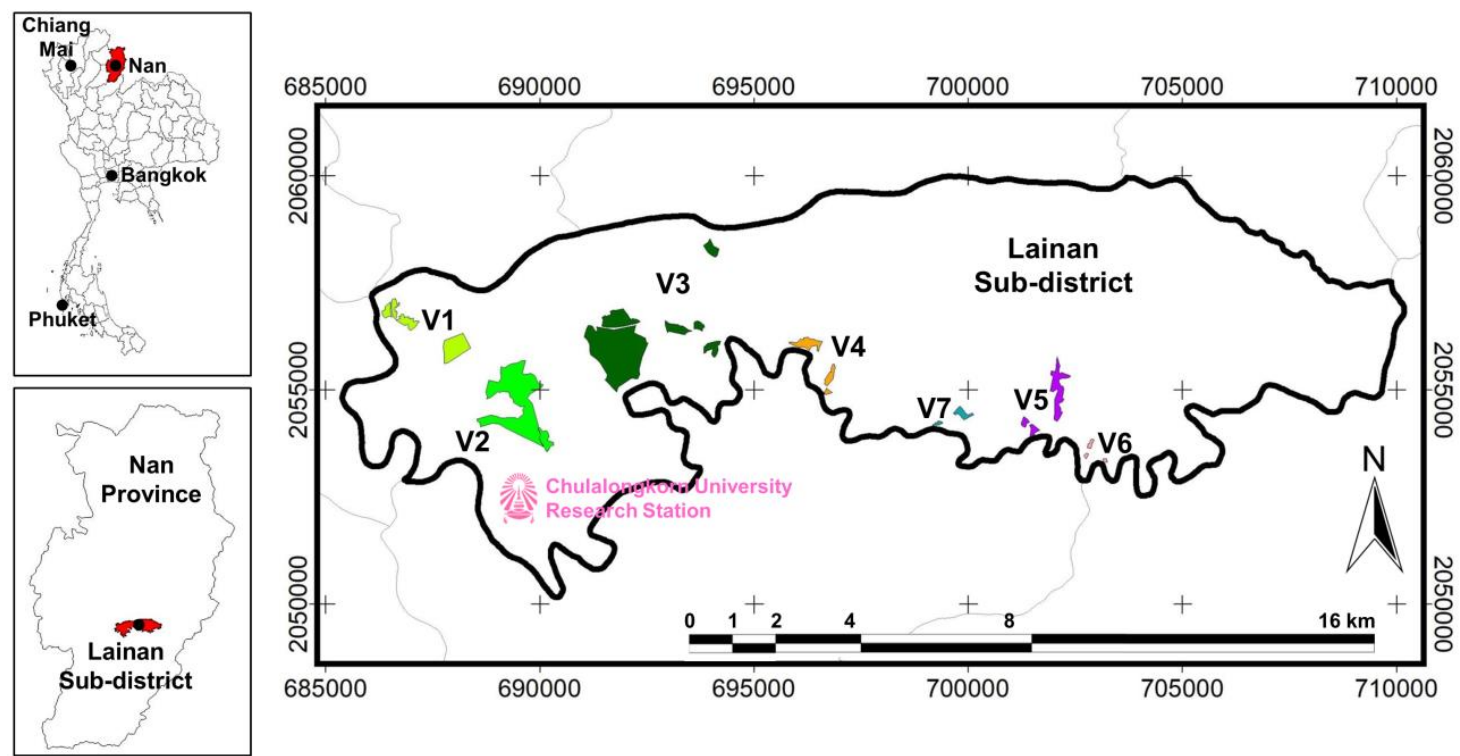

Figure 1: Location of the study site and the seven villages of Lainan Sub-district, Wiang Sa District, Nan Province, northern Thailand.

Table 1: Non-timber forest product harvesting pressure and the community forest rules and regulations of the seven villages at Lainan Sub-district, Wiang Sa District, Nan Province, northern Thailand.

\begin{tabular}{lccccccc} 
& \multicolumn{9}{c}{ Village number } & \multicolumn{2}{c}{} \\
& V1 & V2 & V3 & V4 & V5 & V6 & V7 \\
\hline Total area (ha) & 45 & 134 & 192 & 19 & 31 & 3 & 7 \\
Harvesting pressure & & & & & & & \\
Total number of households (HHs) & 273 & 254 & 149 & 238 & 145 & 47 & 48 \\
Number of harvesting HHs & 184 & 175 & 149 & 25 & 25 & 30 & 48 \\
Estimated number of harvesters & 234 & 225 & 249 & 25 & 25 & 35 & 53 \\
Rules and regulations & & & & & & & \\
Fine for logging (USD/tree) & 167 & 167 & 333 & 33 & 333 & 33 & 50 \\
Fine for wildlife hunting (USD/animal) & 167 & No & 167 & No & No & No & No \\
Fine for dumping waste (USD) & 333 & 333 & 83 & 17 & No & No & No \\
Fine for burning (USD) & No & 333 & 167 & No & No & 17 & No \\
Buddhist religious protection ritual & Yes & No & Yes & No & No & No & No \\
\hline
\end{tabular}

Source: Wimolsakcharoen et al. (2020).

The average population density of lowland Thai people at the study site was 28 inhabitants $/ \mathrm{km}^{2}$ (National Statistical Office, 2020). The majority of the working population farm their own land, but a few villagers are landless, and several settlers are government officers. The major source of income at this site is agriculture, with an average annual income per household of 7,217 USD/household/year (National Statistical Office, 2020).

Wildfires occur regularly in these deciduous community forests during the warm and dry season (March and April). A preliminary diagnostic analysis found that a large number of people travel from other sub-districts, or even other provinces, to harvest NTFPs in the Lainan's community forests as they are less-degraded than other forest areas in the region. In particular, they visit the large forest areas of villages 2 and 3 where large amounts of NTFPs are available (Wimolsakcharoen et al., 2020). Damages to the NTFP resources could be caused by both outsiders and local harvesters due to the gathering of excessive NTFPs per trip, but also their harmful practices (such as using a small rake to search for Astraeus spp. on the forest ground that destroys the mushroom sporophytes prior to spore release and so leads to a potential decline in the mushroom species diversity). However, we found that the amount of NTFPs harvested per trip by local harvesters was usually much lower compared with outsiders' harvests. Local rule-breaking harvesters are generally warned to improve their practices by other local harvesters, especially the landless villagers from the same village (most of the local harvesters gather NTFPs in their own village area). As a result, the harvesting practices of outsiders were found to be more damaging to the NTFP resources compared with the local villagers' practices. 
To prevent damage from wildfires, the establishment of firebreaks was seen as an effective and low-cost practice to be encouraged. Each year, leaf litter and small debris on the forest ground are removed alongside the small pathways across the forest to agricultural areas by volunteers from each individual village (especially in the large community forests of villages 1-3) in order to cut off the spread of wildfire. The CFM committee of each individual village has also attempted for many years to prevent the intrusions of outside harvesters to avoid resource overexploitation, but they have not been successful yet (Wimolsakcharoen et al., 2020). These two topics showed the need for new CFM initiatives and collective action to improve the sustainable management of NTFPs at this site.

\subsection{Model co-design and construction}

During the preliminary field surveys, the community forests of Lainan Sub-district were first analyzed by researchers. The research team then developed a simplified representation of the functioning of this SES. The corresponding conceptual model of an archetypical community forest is presented as the Unified Modelling Language (UML) class diagram (Booch et al., 1997) in Figure S1 in Supplementary Material A.

This first version of the model was implemented as a RPG that was used at the study site during the initial workshop. The objective of this workshop was twofold: (i) to validate this simplified representation with heterogeneous stakeholders; and (ii) to explore possible future scenarios for improving the volume of NTFPs (see more details on the proceedings of the initial workshop in Supplementary Material A). The second version of the model, which took into account the feedback received from the local stakeholders, was represented as a formal conceptual model in a UML class diagram, and described based on the Overview, Design concept, and Details (ODD) protocol (Grimm et al., 2006; 2010).

This new version of the model was implemented as a CRPG using the CORMAS (COmmon-pool Resource and MAS) modelling and simulation platform, which is dedicated to natural and common-pool resource management and uses the Smalltalk object-oriented computer language (Bousquet et al., 1998; Bommel et al., 2016). Several tests and corrections were conducted in the laboratory to verify that the model behaved logically and realistically. The model was verified to ensure its coherence with the conceptual model. All the parameters in the model were also calibrated based on the data obtained from the previous preliminary field studies. After completion of the model verification and calibration in the laboratory, it was submitted to the local stakeholders for their collective validation during a field workshop.

\subsection{Field workshop}

A one-day field workshop was held in January 2018 at Chulalongkorn University Research Station, located nearby the community forests of village 2 (Figure 1), to use the modified model implemented as a cRPG with 21 heterogeneous stakeholders. These included village leaders and CFM committee members who are also the local NTFP harvesters, and sub-district administrative organization (SAO) staff members. They were middle-aged (from 18 to 60 years old) and old (over 60 years old) people comprised of 17 men and four women. Village leaders and SAO staff members were involved in co-designing the model and selecting the workshop participants. Twelve of them were invited to participate in this subsequent workshop because they took part in the previous initial workshop and the co-design of the model in the previous phase (Supplementary Material A). These 12 participants invited nine additional participants who were also village leaders and CFM committee members at their own village.

Beyond the validation of the modified model by the participants, another objective of the workshop was to facilitate the exchange of experiences, knowledge, and perceptions about CFM and NTFP harvesting among the participants, including the research team. Three different participatory gaming and simulation sessions were organized. Individual decisions with no communication between players were implemented in the first session to make the participants familiar with the new CRPG tool, its components, and decision rules. A short debriefing session was held at the end of this first session to validate, or reject and change the features of the simulation tool. This is because it is essential to ensure that the model is acceptable to the stakeholders for them to be eager to use it as a tool for sharing points of view and simulating desired future scenarios (Trébuil et al., 2005). Based on the local participants' propositions during the model co-design phase, the two scenarios on the establishment of firebreaks and the occurrence of outsiders intensively harvesting NTFPs were explored during 
two separate sessions, to stimulate exchanges among the participants, based on their respective experiences, and to initiate a distributed dialogue on how to improve the local CFM management.

At the end of the workshop, the participants discussed the following two topics during a plenary debriefing. Firstly, they compared the results among the three gaming and simulation sessions, based on the total amount of resource units harvested by each player and the overall remaining resource units in the landscape at the end of each session. Secondly, they discussed the similarities and differences between these results and their actual field circumstances, especially the relationships between the roles played in the gaming and simulation sessions and the actual behaviour of the stakeholders. Two days after the workshop, individual in-depth interviews were performed with the participants using a semi-structured guideline, to evaluate the effects of the model use on individual and collective learning regarding the CFM situation and issues, and on changes in the perceptions of the other participants. The second objective was to gather feedback following this event, such as comments on the gaming and simulation tool and its relationship with actual circumstances, on the implementation of the participatory process and its future perspectives, on their engagement, etc. More information on this guideline is provided in Supplementary Material B.

\section{Model description}

We use the ODD protocol (Grimm et al., 2006; 2010) to describe the model.

\subsection{Overview}

The name of the model, CoComForest, stands for COllaborative COMmunity FOREST management. The purposes of this CRPG are to expose local resource harvesters to the competition with external resource harvesters, called outsiders, and to provide them the opportunity to collectively discuss resource management. The model, which is made of a set of interconnected entities, is largely inspired from the initial conceptual model depicted as a UML class diagram in Figure S1 (Supplementary Material A). To achieve these purposes, the three types of local resource harvesters were merged and a new type of outsiders was introduced. The concept of firebreak was also displayed. More details about the main entities of the CoComForest model are given below.

\section{Entities}

Community forest habitat: the abstract landscape was a spatial grid of 25 cells $(5 \times 5)$ representing a 400 ha community forest with spatially distributed heterogeneous NTFP resources. These resources are the three major NTFPs commonly found in the region: (i) young shoots of Melientha suavis, (ii) queen broods of Oecophylla smaragdina (weaver ant), and (iii) wild edible mushrooms (Wimolsakcharoen et al., 2020). Each cell bears a given amount of available resources, which was set at one of five levels as follows: 0 (no resource), 1 (low amount of resources), 2 (medium amount of resources), 3 (high amount of resources), and 4 (very high amount of resources). The resource capacity (i.e. the maximum level of available resources) varied among these cells due to the heterogeneity of habitats in the landscape. In other words, diverse environmental conditions (resulting mainly here from different tree compositions) in the community forests influenced the capacity of the forest habitat to provide NTFP resources (Burton \& Eggleton, 2016).

Resource harvesters: the number of harvesting agents ranged from 20 to 30, and there were two main types of harvesting agents, as follows:

(i) local harvesters in Lainan Sub-district; and

(ii) outsiders from other sub-districts or even other provinces. The participants in the initial workshop requested to introduce this second type of harvester in the model.

Market: this entity buys the resources from the harvesters. The farm gate price of each kind of NTFP is agreed upon by the harvesters at the beginning of the first gaming and simulation session and this price remains constant throughout the successive rounds of play and the following sessions.

Firebreak: the addition of this passive entity was requested by the participants in the initial workshop. In the CoComforest gaming and simulation sessions, the decision to establish firebreaks and their locations in the landscape relied on a collective agreement among the local harvesters. This option was available in all rounds of the second and third sessions of the workshop. The resource capacity of a cell equipped with a firebreak 
increased by one unit because the local stakeholders considered that the potential production of NTFPs was improved due to the prevention of wildfire damage.

\section{Process overview and scheduling}

One round of play corresponded to one year and a gaming and simulation session was composed of at least three successive years. A game round consisted of seven chronologically ordered steps, as shown in Figure 2.

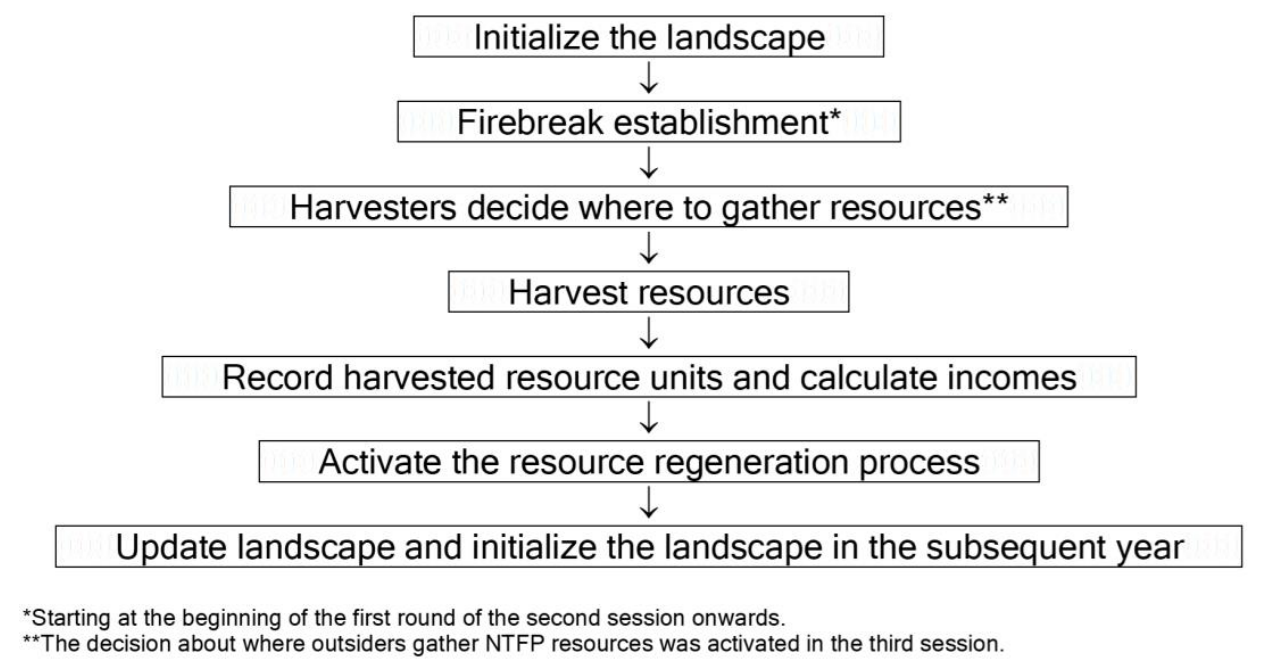

Figure 2: Scheduling of the successive steps in a year simulated by the CoComForest model.

Each player managed only one harvester. Individual decisions without communication among players were played in the first participatory gaming and simulation session, while decisions following exchanges among the participants were played in the second and third sessions simulating the two scenarios. In each round of play of those sessions, the players could coordinate their moves prior to the selection of the cell for their respective harvester.

\subsection{Design concepts}

The design of the CoComForest model (e.g. layout and processes) was initially inspired by the Resource and Habitat (ReHab) gaming and simulation tool (Le Page et al., 2016). The following three complementary theoretical concepts were mobilized in the model design phase:

(i) Common-pool resources: correspond to renewable resources in a natural ecosystem that are openaccess for anyone to use. There is no owner of the resources and appropriators harvesting them gain property rights only on what they harvest (Hess \& Ostrom, 2003).

(ii) Adaptive management and capacity: a learning-based approach involving the fundamental features of learning and adaptation that leads to an improved understanding of the resource system and its dynamics, and an improved management based on that understanding (Williams, 2011). The concept of adaptive capacity, which reflects learning and the ability of groups to act collectively during a crisis or surprise in order to experiment and foster innovative solutions in a SES, can be used to examine common-pool resource management challenges (Armitage, 2005; Cundill \& Fabricius, 2010).

(iii) Adaptive co-management: a flexible governance-based approach to common-pool resource management tailored to specific places and situations. It combines the learning-by-doing approach of adaptive management with the collaborative approach of co-management (Armitage et al., 2009; Schultz et al., 2011).

\subsection{Implementation details}

\section{Initialization}

The initial configuration of the spatial distribution of both resource potentials (Figure $3 a$ ) and actual resource levels (Figure 3b) among the cells of the model's main interface (representing the community forest habitat) was always the same at the start of a gaming and simulation session. The initial resource carrying capacity of the 
landscape (its total resource potential) corresponded to 60 resource units, as defined by the number of cells bearing a given resource level $\left[(10 \times 3)^{1}+(15 \times 2)+(0 \times 1)+(0 \times 0)=60\right]$, and displayed in Figure 3a. There was no cell with resource level 4 at the initial stage as this maximum level depends on human intervention to prevent wildfire damages by establishing firebreaks. The initial resource availability always accounted for half of the carrying capacity as follows: $(3 \times 3)+(5 \times 2)+(11 \times 1)+(6 \times 0)=30$ resource units (see in Figure $3 b)$.

(a)

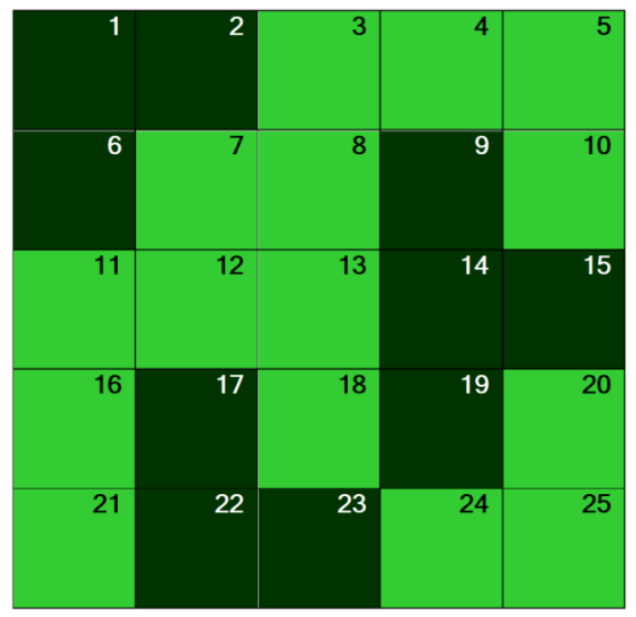

(b)

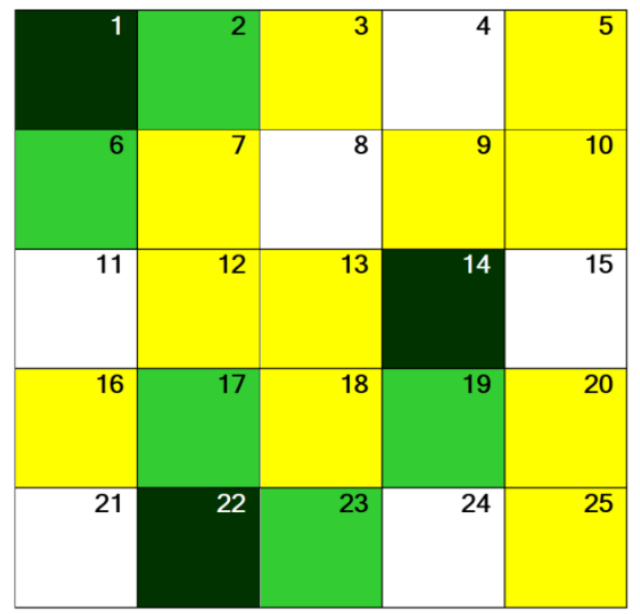

Figure 3: Initial spatial configuration of the resource in the CoComForest model. (a) Resource potentials. Only levels 2 (green) and 3 (dark green) appear at the initialization stage. (b) Resource levels: 0 (white), 1 (yellow), 2 (green), and 3 (dark green).

\section{Input data}

Data on the actual annual production of the three major kinds of NTFPs in the community forests of Lainan Subdistrict obtained during the preliminary field investigations (Wimolsakcharoen et al., 2020) were used to determine the quantity of resources available in the landscape in the absence of any firebreak (Table 2). No data from prior field investigations were available to quantify the effect of establishing a firebreak on the resource availability. Therefore, the increased production potential (Table 2) was established from the experience of the participants. It was decided that this improvement could not exceed twice the amount of resources observed without the firebreak. Therefore, when a firebreak was established, the annual productions of all three major NTFPs doubled.

This model also required input data to select the location of the harvesters. In each round of play of a gaming and simulation session, the harvesters decided on which cell of the landscape they preferred to collect resources from and the model interactively registered their location year by year.

${ }^{1}(10 \times 3)$ means that 10 cells have a resource level equal to 3 . 
Table 2: Amount of resources without and with firebreak establishment corresponding to each resource level (RL).

\begin{tabular}{lcccccc}
\hline \multirow{2}{*}{ Resource } & $\begin{array}{c}\text { Firebreak } \\
\text { establishment }\end{array}$ & $\begin{array}{c}\text { RL 0 } \\
\text { (white) }\end{array}$ & $\begin{array}{c}\text { RL 1 } \\
\text { (yellow) }\end{array}$ & $\begin{array}{c}\text { RL 2 } \\
\text { (green) }\end{array}$ & $\begin{array}{c}\text { RL 3 } \\
\text { (dark green) }\end{array}$ & $\begin{array}{c}\text { RL 4 } \\
\text { (blue) }\end{array}$ \\
\hline \multirow{2}{*}{ Melientha suavis } & No & 0 & 10 & 20 & 30 & $\mathrm{n} / \mathrm{a}$ \\
& Yes & 0 & 20 & 40 & 60 & 80 \\
\hline Oecophylla smaragdina's & No & 0 & 25 & 50 & 75 & $\mathrm{n} / \mathrm{a}$ \\
queen brood & Yes & 0 & 50 & 100 & 150 & 200 \\
\hline \multirow{2}{*}{ Edible mushrooms } & No & 0 & 10 & 20 & 30 & $\mathrm{n} / \mathrm{a}$ \\
& Yes & 0 & 20 & 40 & 60 & 80 \\
\hline
\end{tabular}

\subsection{Sub-models}

(i) Resource harvesting: a local harvester or an outsider could gather resources in only one cell in a given round of play. If several agents visit the same cell, the available resource units are randomly allocated among them based on the probabilities shown in Table 3.

Table 3: Sharing of the resources when more than one harvester is located in a cell in the same round of play.

\begin{tabular}{|c|c|c|c|c|c|c|c|}
\hline \multirow{2}{*}{ No. of agents } & \multirow{2}{*}{ Resource level } & \multirow{2}{*}{$\begin{array}{c}\text { Probability } \\
\text { (\%) }\end{array}$} & \multicolumn{5}{|c|}{ Sharing of the resource units among harvesters } \\
\hline & & & Agent 1 & Agent 2 & Agent 3 & Agent 4 & Agent 5 onwards \\
\hline \multirow[t]{11}{*}{$\geq 4$} & 4 & 55 & 1 & 1 & 1 & 1 & 0 \\
\hline & & 20 & 2 & 1 & 1 & 0 & 0 \\
\hline & & 10 & 2 & 2 & 0 & 0 & 0 \\
\hline & & 10 & 3 & 1 & 0 & 0 & 0 \\
\hline & & 5 & 4 & 0 & 0 & 0 & 0 \\
\hline & 3 & 85 & 1 & 1 & 1 & 0 & 0 \\
\hline & & 10 & 2 & 1 & 0 & 0 & 0 \\
\hline & & 5 & 3 & 0 & 0 & 0 & 0 \\
\hline & 2 & 95 & 1 & 1 & 0 & 0 & 0 \\
\hline & & 5 & 2 & 0 & 0 & 0 & 0 \\
\hline & 1 & 100 & 1 & 0 & 0 & 0 & 0 \\
\hline \multirow[t]{10}{*}{3} & 4 & 50 & 2 & 1 & 1 & $\mathrm{n} / \mathrm{a}$ & $\mathrm{n} / \mathrm{a}$ \\
\hline & & 20 & 2 & 2 & 0 & $n / a$ & $\mathrm{n} / \mathrm{a}$ \\
\hline & & 20 & 3 & 1 & 0 & $\mathrm{n} / \mathrm{a}$ & $\mathrm{n} / \mathrm{a}$ \\
\hline & & 10 & 4 & 0 & 0 & $\mathrm{n} / \mathrm{a}$ & $\mathrm{n} / \mathrm{a}$ \\
\hline & 3 & 70 & 1 & 1 & 1 & $\mathrm{n} / \mathrm{a}$ & $\mathrm{n} / \mathrm{a}$ \\
\hline & & 20 & 2 & 1 & 0 & $\mathrm{n} / \mathrm{a}$ & $\mathrm{n} / \mathrm{a}$ \\
\hline & & 10 & 3 & 0 & 0 & $n / a$ & $n / a$ \\
\hline & 2 & 90 & 1 & 1 & 0 & $\mathrm{n} / \mathrm{a}$ & $\mathrm{n} / \mathrm{a}$ \\
\hline & & 10 & 2 & 0 & 0 & $n / a$ & $n / a$ \\
\hline & 1 & 100 & 1 & 0 & 0 & $\mathrm{n} / \mathrm{a}$ & $\mathrm{n} / \mathrm{a}$ \\
\hline \multirow[t]{8}{*}{2} & 4 & 40 & 2 & 2 & $\mathrm{n} / \mathrm{a}$ & $\mathrm{n} / \mathrm{a}$ & $\mathrm{n} / \mathrm{a}$ \\
\hline & & 40 & 3 & 1 & $\mathrm{n} / \mathrm{a}$ & $\mathrm{n} / \mathrm{a}$ & $\mathrm{n} / \mathrm{a}$ \\
\hline & & 20 & 4 & 0 & $n / a$ & $\mathrm{n} / \mathrm{a}$ & $n / a$ \\
\hline & 3 & 80 & 2 & 1 & $\mathrm{n} / \mathrm{a}$ & $n / a$ & $\mathrm{n} / \mathrm{a}$ \\
\hline & & 20 & 3 & 0 & $n / a$ & $n / a$ & $n / a$ \\
\hline & 2 & 80 & 1 & 1 & $n / a$ & $\mathrm{n} / \mathrm{a}$ & $\mathrm{n} / \mathrm{a}$ \\
\hline & & 20 & 2 & 0 & $\mathrm{n} / \mathrm{a}$ & $\mathrm{n} / \mathrm{a}$ & $n / a$ \\
\hline & 1 & 100 & 2 & 0 & $\mathrm{n} / \mathrm{a}$ & $\mathrm{n} / \mathrm{a}$ & $\mathrm{n} / \mathrm{a}$ \\
\hline Single agent & $1-4$ & 100 & $1-4$ & $\mathrm{n} / \mathrm{a}$ & $\mathrm{n} / \mathrm{a}$ & $\mathrm{n} / \mathrm{a}$ & $\mathrm{n} / \mathrm{a}$ \\
\hline
\end{tabular}

(ii) Influence of visiting harvesters on resource regeneration: in each round of play, the total number of visiting harvesters on a cell influenced the resource regeneration process. Based on the information gathered during the preliminary field investigations, we considered that damages occur occasionally due to the harmful harvesting practices of outsiders (Wimolsakcharoen et al., 2020). Therefore, when outsiders visit a cell, its resource level decreases to zero. In the case of different local harvesters visiting the same cell, their number affects the subsequent resource level as shown in Figure 4 and outlined as follows: 
(a) When more than two local harvesters visited a cell, the resource level decreased to zero.

(b) When only two local harvesters visited the cell, its resource level decreased by one unit.

(c) The resource level increased when there were no visiting local harvesters, and it did not change when only one local harvester visited the cell.

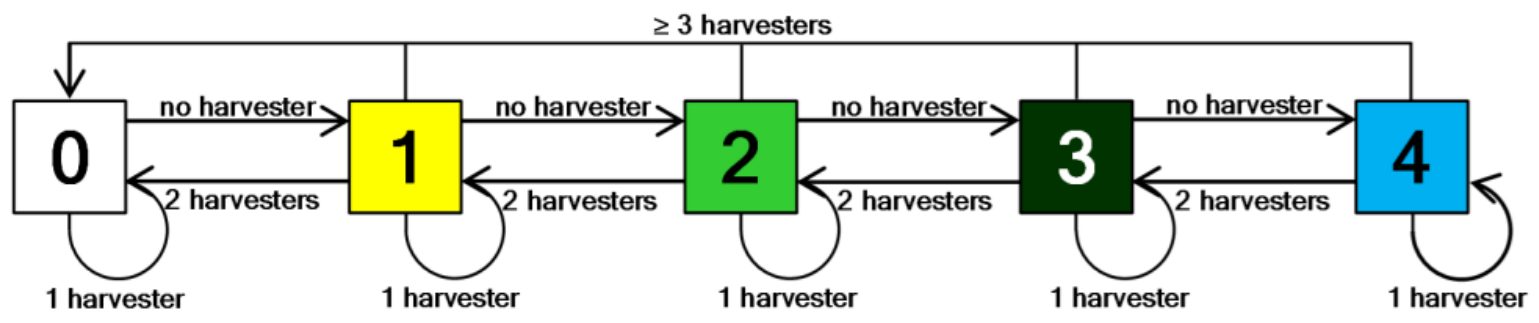

Figure 4: State-transition diagram of the resource level dynamics according to the number of visiting local harvesters on a given cell.

\section{Results}

\subsection{Outcomes from the participatory gaming and simulation sessions}

\section{(i) Co-validation of the CRPG with local stakeholders in the first session}

At the beginning (rounds 1 and 2) of the first session, the participants were briefed about the spatial features of the grid, especially the significance of the four different colours that represent the resource level of each cell. Most of the other model functionalities, such as the amount of harvested resources, the income obtained from selling harvested resources, the resource regeneration process influenced by the number of visiting agents, etc., as well as the scheduling of a round of play, were considered by the players to be similar to what they experience in their actual harvester life. At the end of the first session, no requests to change the model features or functionalities were received from the participants. This is because this CRPG was developed as an in silico version of the initial RPG previously used and co-validated with local stakeholders. Consequently, the same model was used in the subsequent second and third sessions.

\section{(ii) Firebreak establishment and declaration of protected areas in the second session}

At the beginning of the second session, the participants selected three different cells in the landscape to establish firebreaks (Figure 5a). Most of them considered that the firebreaks should be established in the resource-abundant areas to maintain a high level of resources. But a few of them thought that the firebreaks should be created in the degraded areas to rehabilitate them. Finally, the firebreaks were created on two resource-rich cells (resource level $\geq 2$ ) and the last one on a resource-poor cell. The players agreed to maintain the firebreaks at the same location throughout the whole session as this is their practice in actual circumstances.

Additionally, one SAO staff member asked to declare protected areas in the landscape where the players were not allowed to harvest resources. In rounds 1 and 2, the players agreed to declare the protected areas in the cells equipped with the firebreaks (Figures $5 \mathrm{a}$ and $5 \mathrm{~b}$ ). But in round 3 , a player proposed to locate the protected areas in the contiguous resource-rich cells to boost the resource availability, and consequently the two contiguous resource-level-2 cells were declared as protected in this final round of the session (Figure 5c). 
(a) Round 1 of Session 2

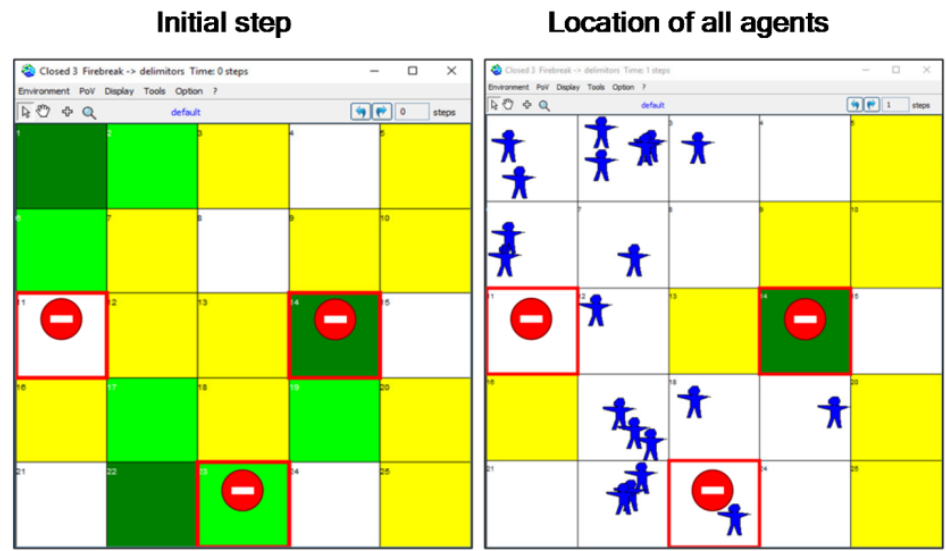

(b) Round 2 of Session 2

Initial step

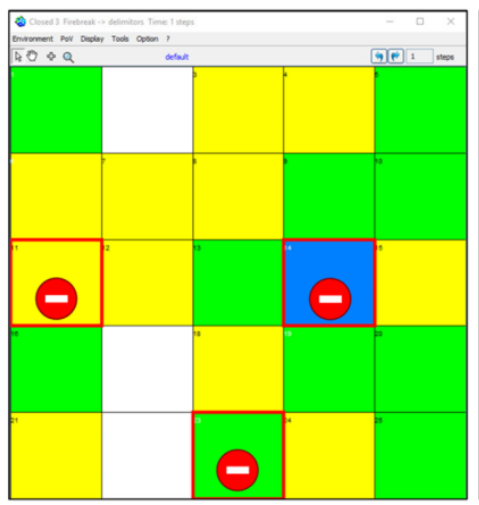

(c) Round 3 of Session 2

Initial step

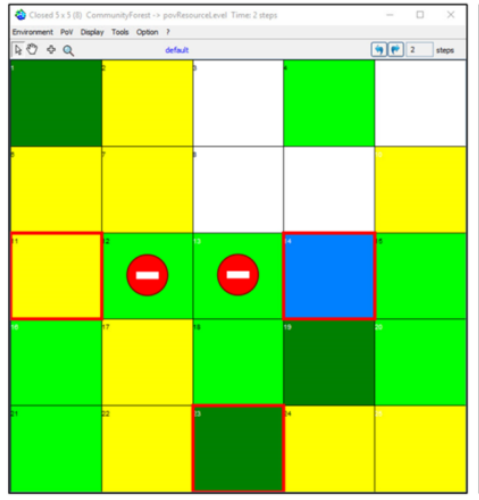

Location of all agents

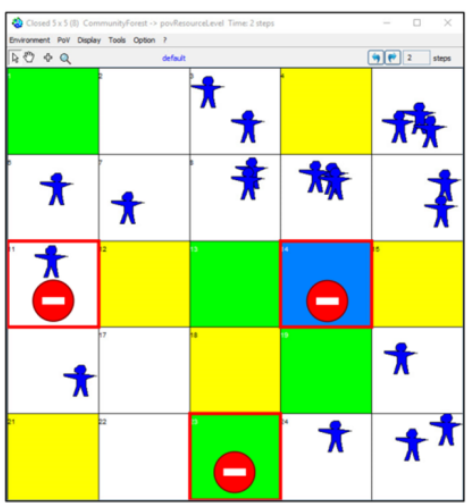

Location of all agents

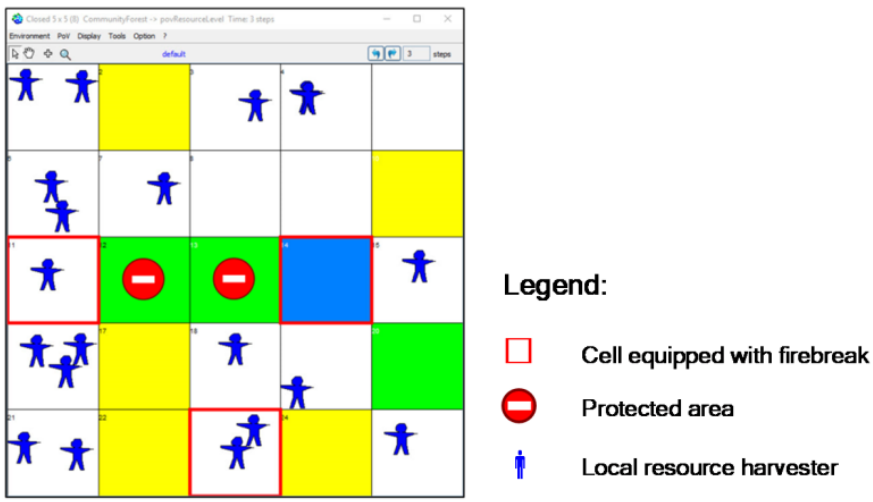

Figure 5: Screen captures from the three rounds of the second gaming and simulation session in which firebreaks were established and protected areas were declared.

During the first two rounds, one player broke the rule by harvesting resources in a protected area in each round (as shown in Figures $5 \mathrm{a}$ and $5 \mathrm{~b}$ ) and disturbed the resource regeneration on those cells. Consequently, before starting round 3, a penalty was introduced by the SAO staff members and researchers for violators harvesting resources in the protected cells: they would be fined 33 USD and all their harvest would be confiscated at the end of the round. This rule was effective as no harvester trespassed to gather resources in the protected cells in this third round (Figure 5c). 


\section{(iii) Introduction of outsiders intensively harvesting NTFPs in the third session}

The firebreaks and protected areas options remained in place in this third session. But, as proposed by the local stakeholders when the initial RPG was used with them, the occurrence of outsiders intensively harvesting NTFPs was a scenario that was simulated and assessed in this session. Three outsiders were played by the SAO staff members to simulate the rate of depletion of the NTFP resources due to the outsiders' damaging practices. The objective of outsiders - to collect as many NTFPs as possible in a single trip - was already well known (Wimolsakcharoen et al., 2020) and shared among the participants. In the first round, the firebreaks were established in the three contiguous cells and the two adjacent contiguous cells were selected as the protected areas (Figure 6a). While the reasons behind the players' decision to select this option were not clearly expressed, this choice looks like an implementation of the island biogeography theory. This theory assumes that one large conserved area has a higher species diversity, loses species more slowly, and better preserves the full range of successional communities and patch dynamics within ecosystems compared to several fragmented and smaller conserved areas (MacArthur \& Wilson, 2001; Laurance, 2008). The firebreaks remained at the same location as in the second session throughout the following session, but in the second round, the players agreed to move the two protected cells to another two contiguous cells lacking resources at the top of the grid to rehabilitate this degraded area (Figure 6b).

At the end of the final round of the third session, only two green (level 2) resource-rich cells were left (Figure $6 \mathrm{c}$ ), while there were four resource-rich cells, including one level-4 (blue) cell and three level-2 (green) cells, at the end of the final round of the second session in the absence of outsiders (Figure $5 \mathrm{c}$ ). As expected, and similar to the local stakeholders' observations, this illustrated the negative impact of the outsiders' intensive harvesting practices on the dynamics of resources in the landscape. But the final amount of resources could have been lower because the outsiders (played by the local SAO staff members) did not visit the protected cells throughout the whole third session (Figure 6). It can be assumed that actual outsiders would visit the protected areas as well to maximize the amount of NTFPs harvested per trip to compensate for their higher transport costs and longer travelling times (Wimolsakcharoen et al., 2020).

\subsection{Comparison of ecological and economic indicators}

In the second session, the average income per harvester and the remaining resource units at the end of the session were higher compared to the first session (Table 4). This was a consequence of the players' collective agreement to improve the availability of resources by preventing wildfire damages and rehabilitating the forest landscape through the protected areas. In the third session, the values of all indicators decreased compared to the previous two sessions (Table 4). The average cumulated income per harvester dropped by $34 \%$, and the amount of remaining resources at the end of the session decreased by $40 \%$ compared to the second session following the intensive harvesting practices of outsiders, which accelerated the depletion of resources in the landscape.

Table 4: Average cumulated resource units harvested (units/harvester/session), income (USD/harvester/session), and amount of remaining resource units in the landscape at the end of each session (units).

\begin{tabular}{cccc}
\hline $\begin{array}{c}\text { Gaming and } \\
\text { simulation } \\
\text { session (S) }\end{array}$ & $\begin{array}{c}\text { Average cumulated resource } \\
\text { units harvested } \\
\text { (units/harvester/session) }\end{array}$ & $\begin{array}{c}\text { Average cumulated income } \\
\text { (USD/harvester/session) }\end{array}$ & $\begin{array}{c}\text { Amount of remaining } \\
\text { resource units in the } \\
\text { landscape at the end of each } \\
\text { session (units) }\end{array}$ \\
\hline S1 & 3 & 1,284 & 10 \\
S2 & 3 & 1,303 & 15 \\
S3 & 2 & 863 & 9 \\
\hline
\end{tabular}


(a) Round 1 of Session 3

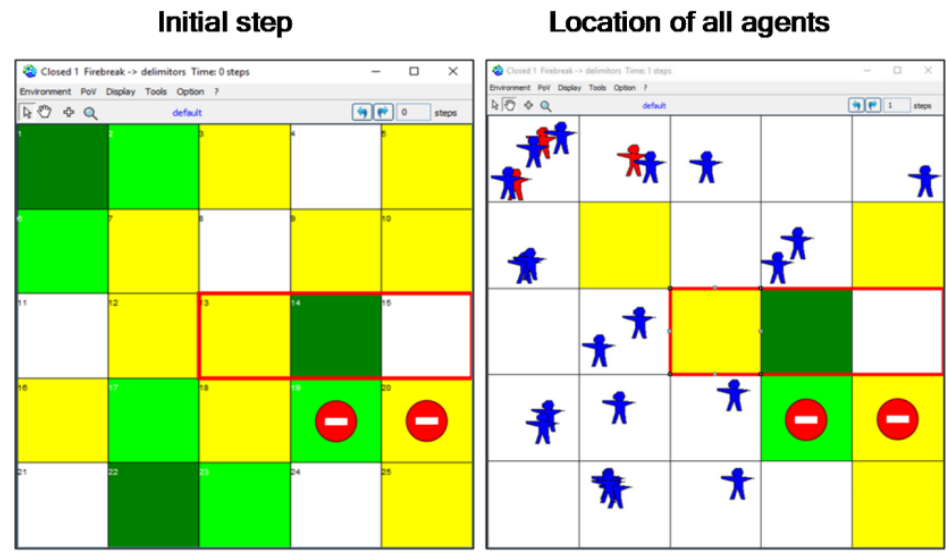

(b) Round 2 of Session 3

Initial step

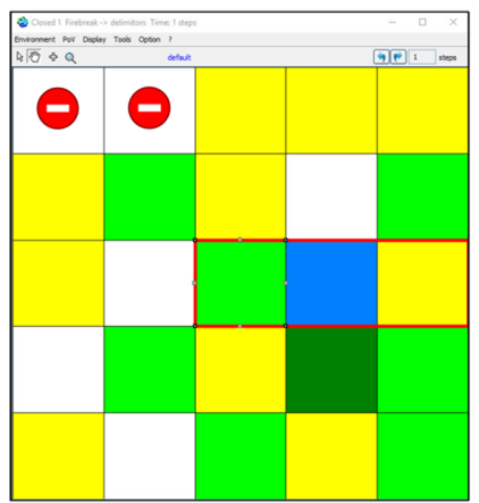

(c) Round 3 of Session 3

Initial step

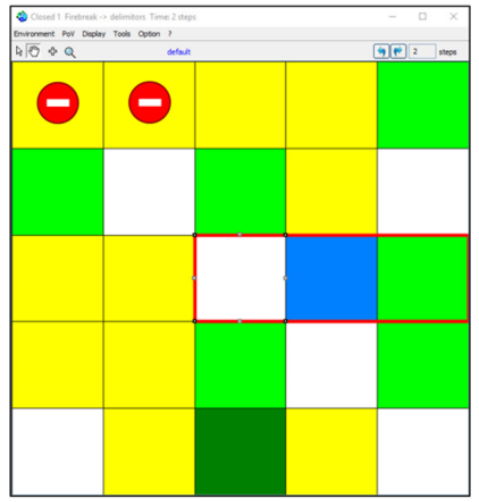

Location of all agents

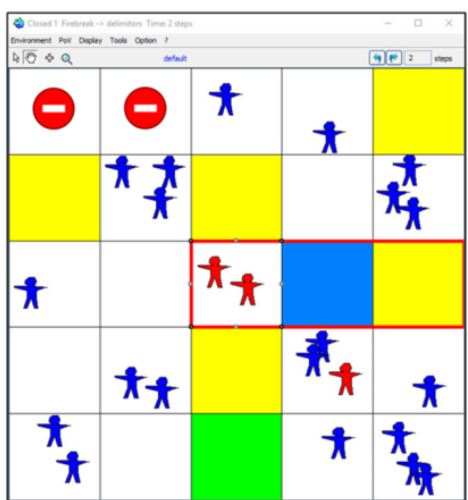

Location of all agents

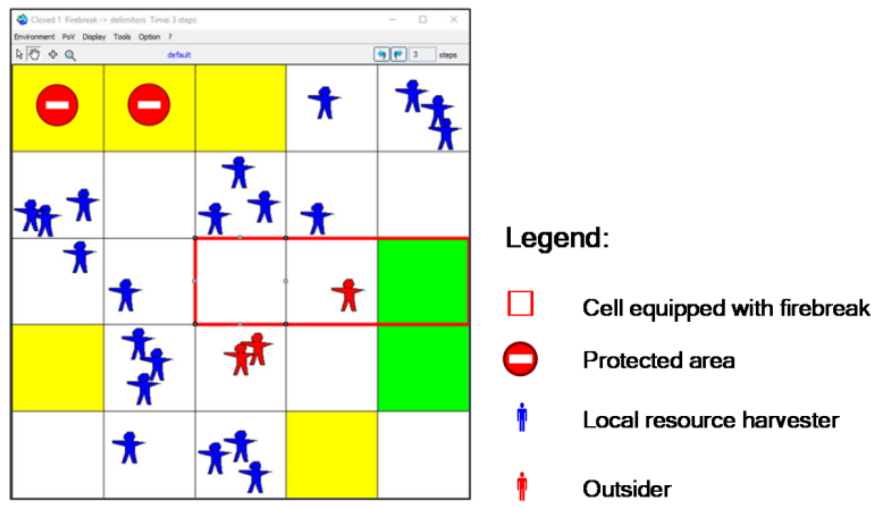

Figure 6: Screen captures from successive rounds of the third gaming and simulation session in which outsiders harvested resources on the landscape.

\subsection{Players' decision-making}

In the first round of the first session, most players tried to harvest as much resources as possible by visiting resource-rich cells, especially resource level 3 (S1Y1 in Table 5a). After noticing that the resource level of those cells would decrease rapidly if several harvesters visited them, the number of players selecting those cells decreased in the subsequent two rounds of the first session, as well as in the subsequent two sessions. In the second session, where collective decisions among the players were allowed to avoid their visiting at the same cell, a higher number of players harvested resources from cells with a low resource level (1) compared to the first session (Table 5a). This group of players explained that, in reality, their households only needed a small 
amount of resources for self-consumption as they managed relatively large farms. This illustrates the fact that the decision-making of players in these simulated situation sessions mimicked their real-life strategy and practices.

Table $5 \mathrm{~b}$ recapitulates the behaviour of the outsiders in each round of play of the third session. Because their strategy was to maximize the amount of harvested resources, these outsiders visited only resource-rich cells in each round of play. In the final round, one of them decided to harvest resources in the maximum resource level (4, blue cell) equipped with a firebreak. This illustrates the practices of these outsiders, guided by a very shortterm interest and a lack of attention to the collective improvement of resource management at the landscape level.

Table 5: Number of resource harvesters located on the cells and the initial number of cells in each resource level in each round of play: (a) local harvesters only, and (b) outsiders.

(a)

\begin{tabular}{|c|c|c|c|c|c|}
\hline \multirow{2}{*}{$\begin{array}{l}\text { Round of play }(\mathrm{Y}) \text { of each } \\
\text { gaming and simulation } \\
\text { session }(\mathrm{S})\end{array}$} & \multicolumn{5}{|c|}{$\begin{array}{l}\text { Number of local harvesters located on the cells and the initial number of cells (in } \\
\text { bracket) in each resource level (RL) in each round of play }\end{array}$} \\
\hline & RL 0 & RL 1 & RL 2 & RL 3 & RL 4 \\
\hline S1Y1 & $0(6)$ & $1(11)$ & $6 \quad(5)$ & $13(3)$ & $\mathrm{n} / \mathrm{a}$ \\
\hline S1Y2 & $1(4)$ & $1(7)$ & $11(12)$ & $7(2)$ & $\mathrm{n} / \mathrm{a}$ \\
\hline S1Y3 & $1(4)$ & $3 \quad(5)$ & $13(15)$ & $3(1)$ & $\mathrm{n} / \mathrm{a}$ \\
\hline S2Y1 & $0(6)$ & $4(11)$ & 11 (5) & $5(3)$ & $0(0)$ \\
\hline $\mathrm{S} 2 \mathrm{Y} 2$ & $0(3)$ & $8(11)$ & $12(10)$ & $0(0)$ & $0(1)$ \\
\hline $\mathrm{S} 2 \mathrm{Y} 3$ & $0(4)$ & 6 (9) & $9(8)$ & $5(3)$ & $0(1)$ \\
\hline S3Y1 & $0(6)$ & $9(11)$ & $5 \quad(5)$ & $6(3)$ & $0(0)$ \\
\hline S3Y2 & $0(6)$ & $6(10)$ & 12 (7) & $2(1)$ & $0(1)$ \\
\hline $\mathrm{S} 3 \mathrm{Y} 3$ & $0(6)$ & $8(11)$ & $9 \quad(6)$ & $3(1)$ & $0(1)$ \\
\hline
\end{tabular}

(b)

\begin{tabular}{cccccc}
\hline $\begin{array}{c}\text { Round of play }(\mathrm{Y}) \text { of } \\
\text { the third gaming and } \\
\text { simulation session (S) }\end{array}$ & \multicolumn{5}{c}{$\begin{array}{c}\text { Number of outsiders located on the cells and the initial number of cells (in bracket) in } \\
\text { each resource level (RL) in each round of play }\end{array}$} \\
\hline S3Y1 & RL 0 & RL 1 & RL 2 & RL 3 & RL 4 \\
\hline S3Y2 & $0(6)$ & $0(11)$ & $1(5)$ & $2(3)$ & $0(0)$ \\
S3Y3 & $0(6)$ & $0(10)$ & $* 2(7)$ & $1(1)$ & $0(1)$ \\
\hline
\end{tabular}

*Outsiders harvesting resources on the cell equipped with a firebreak.

\subsection{Players' learning and new management options}

In the first session, a single player decided to harvest resources in the same cell throughout the three rounds. This cell had an initial resource level of 3 , but no resources were available in the second and third rounds. The player thought that an area with an initially high resource level would provide enough resources every year to meet his/her needs, but after the workshop he/she was able to explain how too many resource harvesters selecting the same spot influenced the decline of the resources in subsequent years even in initially resourceabundant areas.

For collective learning leading to the adaptation of resource management, more than $80 \%$ of the participants agreed that there was a high harvesting pressure in the third session due to the introduction of outsiders. The results from this session supported the analysis of the CFM problem created by the harvesting practices of outsiders, and stimulated a debate about the options available to prevent outsiders in the local community forests. Management options were proposed by the participants during the debriefing phase, such as:

(i) Collectively observe who are the outsiders and where do they come from in order to officially inform the authorities of their villages that they are not permitted to harvest NTFPs in the Lainan's community forests.

(ii) Establish rules and regulations for CFM at the sub-district level and officially announce them to the public by posting them at the edge of each community forest, particularly the ones located along the rural roads. 
To enforce the CFM rules and regulations and to translate these CFM strategies into actual actions, most of the participants agreed on the necessity to set up a new committee for CFM at the sub-district level. Several village leaders also requested to organize additional gaming and simulation sessions in their villages, particularly with young villagers (less than $18 \mathrm{y}$ old) to boost their future collaboration in CFM at the sub-district level.

\section{Discussion}

The CoComForest model was implemented as a cRPG and used with heterogeneous local stakeholders during the field workshop comprised of three participatory gaming and simulation sessions with different objectives as follows: (i) to co-validate the model with the local stakeholders, (ii) to assess the establishment of firebreaks and the declaration of protected areas on the resource dynamics, and (iii) to evaluate the effects of outsiders intensively harvesting local NTFPs. The simulation results from the sessions stimulated most of the participants to share their points of view and analyze the CFM problems addressed in the second and third sessions, especially the issue of outsiders' damaging practices and intensive harvesting of NTFPs in the community forests. New management options (communication with the outsiders' village authorities, establishment of CFM rules and regulations at the sub-district level, and their communication to NTFP harvesters in the community forests) to deal with this problem were debated and suggested during the closing plenary debriefing, but they still need to be shared with more local villagers.

\subsection{Level of stakeholder participation}

The engagement of local people in the bottom-up CFM process is essential to provide an opportunity for community empowerment due to a forum through which various types of local stakeholders can express their perceptions and concerns and participate in the decision-making process (Fraser et al., 2006; Khadka \& Vacik, 2012). Due to the local socio-cultural context, very few local villagers were invited to participate in this early stage of the research project (see more details in Supplementary Material A). In order to strengthen collaboration in CFM, more local villagers should be invited to participate in the future gaming and simulation sessions.

The previous phases of the research project showed that it was difficult to invite outsiders to participate in the ComMod process, and the unanimous opinion of the participants was to try to keep outsiders away from the community forests and not to initiate a negotiation with them. Consequently, actual outsiders were absent in the workshop, and some of the SAO staff members were asked to play the role of outsiders in the last gaming and simulation session. Diverse practices coexisted among the ComMod practitioners when dealing with the absence of important stakeholders. In few cases, the participatory process was interrupted if important stakeholders were absent. However, in other cases, and this one, volunteer participants were assigned to play the role of absent stakeholders (Ruankaew et al., 2010).

In spite of the above-mentioned collective learning aspects generated by the participatory gaming and simulation sessions, a two-way flow of information was observed only between a small group of local stakeholders (village leaders and SAO staff members) and the researchers. There was no iterative and two-way flow of information between them and the participating local villagers, which is one key criterion for determining a 'high' level of participation leading to "increased citizen power" through discussion on different and diverse perspectives (Hurlbert \& Gupta, 2015). Based on "the split ladder of participation" proposed by Hurlbert \& Gupta (2015), the stakeholder participation in this case study, therefore, remained at the level of "seeking (CFM) strategies" and "testing ideas" with CFM strategies explored through the CoComForest simulations in the second and third sessions. To build on the results of the early sequence of a participatory modelling and simulation process reported here, additional similar events need to be conducted by engaging more local villagers (particularly young ones) to promote a more distributed iterative flow of information, and to increase the level of stakeholder participation in the future CFM (Barnaud et al., 2013; Daré et al., 2018).

\subsection{Factors correlated to social learning}

Herrero et al. (2019) proposed three factors that strongly correlated with the social learning generated by participatory research processes in the field of integrated natural resource management (INRM) as follows: (i) 
clarification of the normative background, (ii) openness in the co-construction mode, and (iii) balancing distribution of power (resources/powerful stakeholders).

In this case study, the researchers clarified their goal to promote collaborative CFM at the sub-district level to the local stakeholders since the beginning of the research project. This transparent objective was necessary to build trustful interactions among all the participants. Several methods and tools, including a cRPG, were used to promote dialogue and open discussions for the local stakeholders to share their experiences and better understand each other's viewpoints and motivations on the collective CFM problem. Qualitative and quantitative tools and methods were mixed along the participatory research process. Combining well-tested qualitative methods with semi-quantitative tools, such as a CRPG, enabled hybridizing scientific aspects with knowledge from non-academic stakeholders. Our study, therefore, strengthens the statement that collaborative research approaches based on mixed methods are useful to sustainability science (Myllyviita et al., 2014).

The methods and tools of this research were initially selected by the research team, but a co-construction mode was activated from the beginning of the participatory modelling and simulation process, especially through the sharing of knowledge during the preliminary diagnostic field activities and the initial gaming session, to co-design the model to be used in the workshop. The proposed tools were modified accordingly and the simulations were based on local stakeholders' requests and topics of interest (effects of firebreaks and outsiders' impacts on the resources). The plenary debriefing showed that the three participatory gaming and simulation sessions not only generated a collective understanding on the current CFM problem, but also helped to clarify several agreed upon collective options to improve the CFM problem. The following quote from a participant is illustrative: "this game reflected actual situations in the CFM and made me realize that visiting by outsiders is an urgent issue that needs to be managed". New participatory gaming and simulation sessions will focus on the problem of outsiders and the foundation of a new committee for CFM at the sub-district level, and will also aim at reinforcing the openness of the participatory process and strengthening the co-construction mode compared to the initial sequence to strengthen the collaborative character of this process.

During the plenary debriefing, several facilitation techniques (such as giving equal attention to all the participants' perceptions) were used to ensure that every viewpoint and opinion was voiced. Four local villagers remained passive even though the research team facilitator attempted to provide a synthesis of the perspectives of other participants. The individual interviews after the workshop showed that these four local villagers did not understand the gaming and simulation results because of the power asymmetry between villagers and their leaders. The initial survey and workshop showed that most of Lainan people usually avoid public participation, or keep quiet when they attend meetings with the village leaders, because they consider that they have less abilities and knowledge in CFM. Consequently, these villagers tended to remain passive during the plenary debriefing.

An analysis of local power dynamics can help to deal with such social inequities and power asymmetries to improve stakeholder participation (Barnaud et al., 2010). The selection of participants was carefully implemented during the research design to take this socio-cultural aspect into account. Initially, the organizers did not aim to alter the social distribution of power in the CFM and planned to invite only village leaders and SAO staff members to participate in this early stage of the research project. However, a few village leaders who could not join the workshop sent local villagers to replace them. This created the above-mentioned unequal degrees of participation and power asymmetries among the workshop participants. Due to the importance of the diversity of participants and cross-learning between these unequal participants, there is the need to initiate a dialogue between the CFM managers and the more passive NTFP harvesters. Because a single field workshop cannot suffice to change the situation significantly, similar events should be repeated.

The research team tried to activate the three factors correlated to social learning, as seen through the outcomes of this participatory gaming and simulation workshop, because their systematic combination is necessary to generate strong social learning (Herrero et al., 2019).

\subsection{Linkage between RPGs and ABMs: joint use versus hybridization}

Bakhanova et al. (2020) proposed to categorize the games used into participatory modelling processes in three types: (i) non-model-based games; (ii) model-based games, and (iii) social simulation games. The RPGs fall into the last category. Nowadays, their relevance in supporting the design of ABMs is well established (Janssen \& 
Ostrom, 2006; Robinson et al., 2007). Non-model-based games can also improve the level of clarity along the pathway from evidence to model design. For instance, the research on smallholder families from southeast Cameroon (Bharwani et al., 2015) showed how "game-interviews" can elicit important qualitative aspects of local strategies that build community adaptive capacity and support sustainable forest management. In that case, rule-based outputs from the game-interviews were used as inputs of an ABM.

In the ComMod approach, RPGs are not restricted to an empirical method for building ABMs (Bousquet et al., 2002). Rather, $A B M s$ are well suited to simulate rapidly complex systems and resource dynamics in order to allow stakeholders to explore the potential consequences of various choices in collective decision-making processes. Although, stakeholders may perceive it as a black box not to be trusted (Barreteau \& Abrami, 2007), RPGs are powerful tools "to open such a black box" by empowering stakeholders to enrich the underlying model and better relate its contents to their actual situation and concerns. Moreover, simulating SESs using RPGs can by itself support a deliberative process aimed at stimulating social learning among participants (Whitfield et al., 2011). Yet a RPG is rather time and labour intensive to design and use, and the experimental results of gaming sessions are difficult to reproduce due to numerous uncontrolled factors (Barreteau et al., 2003b; Barreteau \& Abrami, 2007). Hybridizing ABMs and RPGs into a single cRPG for interactive participatory agent-based simulation (Le Page \& Perrotton, 2018) makes it possible to combine the respective strengths of an autonomous ABM and a RPG (more details in Table S1 in Supplementary Material C).

In the process we have conducted, local villagers remained passive during the plenary debriefing at the end of the initial workshop (see end of Supplementary Material A) and did not propose any desired future scenario for sustainably harvesting NTFPs in their community forests. Only the introduction of the firebreak was proposed for testing by a group of village leaders (see more details in Supplementary Material A). Therefore, only the village leaders, CFM committee members, and SAO staff members were invited to participate in the subsequent workshop to explore further desired scenarios. Because intensive participant-to-participant interactions are compulsory to stimulate the exchange of viewpoints, we decided to use the CoComForest model as a cRPG for such a purpose (Thavikulwat, 2009).

At the end of the subsequent workshop reported here, several village leaders requested the organization of similar events in their village involving more young people. To comply with their request, we intend to use the CoComForest model as a RPG in the future sequences of the research project in which the players will be able to calculate the harvested resources and update the landscape accordingly by themselves without the support of a computer. This choice of a RPG as a key simulation tool seems to be suitable to promote intensive interactions and cross-generational knowledge exchange among the participants. This will also allow us to see whether those village leaders could be trained as facilitators of future gaming and simulation sessions in order to make them more autonomous. Barreteau et al. (2001) argued that a RPG can be used for the purpose of not only negotiation support, but also training (Ferrand et al., 2009; Barreteau et al., 2012). Organizing a specific workshop may be necessary for training them to be facilitators in subsequent field workshops. These trained leaders could support new participants discovering the RPG. Additionally, it would be interesting to switch local harvesters to play the role of outsiders to better understand why they enter the community forests to gather NTFP resources. This could promote learning across different perspectives among the variety of stakeholders, a topic which is still challenging for using RPGs in the field of INRM (Edwards et al., 2019).

At the sub-district level, the participants also proposed to invite external agencies, such as (i) the Royal Forest Department (at provincial and regional levels) and (ii) Hug Mueang Nan Foundation (groups of Buddhist monks, local villagers, and youths living in Nan Province supporting environmental conservation), to participate in future sequences of this research project. Several previous case studies suggested that an autonomous ABM could be time efficient in supporting negotiation and collective decision-making among a larger number of diverse stakeholders that are already familiar with the underlying model (Promburom, 2010; Ruankaew et al., 2010; Dumrongrojwatthana et al., 2011). Therefore, the implementation of an autonomous ABM could be another alternative simulation tool that can be used in future activities at the sub-district level, particularly to rapidly display the effects on resource availability and peoples' incomes of the CFM propositions that emerged from the gaming and simulation workshops. Past case studies have shown that such a tool could play a key role in out-scaling (many villages facing similar CFM problems) this type of activities, as well as in up-scaling to engage key decision-makers at higher organizational levels having limited time to attend. 


\section{Conclusion}

The results from this study showed that adapted ways to improve the local CFM have been identified and agreed upon by the workshop participants. More than $80 \%$ of the participants agreed that the CoComForest model, implemented as a CRPG, promoted a common understanding of the CFM problem situation, especially the (quantitatively) negative effects of resource (over)-harvesting by outsiders at the end of the last session. This created a mutual agreement among the participants about the urgent need to better manage the intensive harvest of NTFPs by outsiders, leading to a collective search for acceptable propositions to improve CFM at the sub-district level in the debriefing phase.

To translate the suggestions from the workshop participants into an actual action plan, further similar gaming and simulation workshops with more diverse stakeholders, particularly young villagers, are still necessary. The rather generic and simple CoComForest model and its associated cRPG tool tested in this case study could be useful to facilitate the improvement of collaborative CFM at other sites facing similar problems in Southeast Asian uplands.

\section{Acknowledgements}

The authors thank the Lainan villagers who participated in co-designing the model and in the participatory gaming and simulation sessions. We thank Dr. Pierre Bommel and Dr. Warong Naivinit for helping to prepare the UML diagrams. We are grateful for the constructive comments provided by four anonymous reviewers. The financial contributions of the $90^{\text {th }}$ Anniversary of CU Scholarship, the Sponsorship for Graduate Student Research under CU Academic Network in the Region (CU-ANR-60-01), the Royal Government of Thailand Scholarship under the DPST Project, and the RSPG are also gratefully acknowledged.

\section{References}

Armitage, D. (2005). Adaptive capacity and community-based natural resource management. Environmental Management, 35(6), 703-715. https://doi.org/10.1007/s00267-004-0076-z

Armitage, D. R., Plummer, R., Berkes, F., Arthur, R. I., Charles, A. T., Davidson-Hunt, I. J., Diduck, A. P., Doubleday, N. C., Johnson, D. S., Marschke, M., McConney, P., Pinkerton, E. W., \& Wollenberg, E. K. (2009). Adaptive co-management for social-ecological complexity. The Ecological Society of America, 7(2), 95-102. https://doi.org/10.1890/070089

Bah, A., Touré, I., Le Page, C., Ickowicz, A., \& Diop, A. T. (2006). An agent-based model to understand the multiple uses of land and resources around drillings in Sahel. Mathematical and Computer Modelling, 44, 513-534. https://doi.org/10.1016/j.mcm.2005.02.014

Bakhanova, E., Garcia, J. A., Raffe, W. L., \& Voinov, A. (2020). Targeting social learning and engagement: what serious games and gamification can offer to participatory modeling. Environmental Modelling \& Software, 134, 104846. https://doi.org/10.1016/j.envsoft.2020.104846

Barnaud, C., Le Page, C., Dumrongrojwatthana, P., \& Trébuil, G. (2013). Spatial representations are not neutral: lessons from a participatory agent-based modelling process in a land-use conflict. Environmental Modelling \& Software, 45, 150159. https://doi.org/10.1016/j.envsoft.2011.11.016

Barnaud, C., Promburom, T., Trébuil, G., \& Bousquet, F. (2007). An evolving simulation and gaming process to facilitate adaptive watershed management in mountain northern Thailand. Simulation \& Gaming, 38(3), 398-420. https://doi.org/10.1177/1046878107300670

Barnaud, C., Van Paassen, A., Trébuil, G., Promburom, T., \& Bousquet, F. (2010). Dealing with power games in a Companion Modelling process: lessons from community water management in Thailand highlands. Journal of Agricultural Education and Extension, 16(1), 55-74. https://doi.org/10.1080/13892240903533152

Barreteau, O., \& Abrami, G. (2007). Variable time scales, agent-based models, and role-playing games: the PIEPLUE river basin management game. Simulation \& Gaming, 38(3), 364-381. https://doi.org/10.1177/1046878107300668

Barreteau, O., Abrami, G., Daré, W., Du Toit, D., Ferrand, N., Garin, P., Souchère, V., Popova, A., \& Werey, C. (2012). Collaborative modelling as a boundary institution to handle institutional complexities in water management. In H. A. Karl, L. Scarlett, J. C. Vargas-Moreno, \& M. Flaxman (Eds.), Restoring Lands - Coordinating Science, Politics and Action: complexities of climate and governance (pp. 109-127). Springer Science \& Business Media. https://doi.org/10.1007/978-94-007-2549-2_6

Barreteau, O., Antona, M., D’Aquino, P., Aubert, S., Boissau, S., Bousquet, F., Daré, W., Étienne, M., Le Page, C., Mathevet, R., Trébuil, G., \& Weber, J. (2003a). Our companion modelling approach. Journal of Artificial Societies and Social Simulation, 6(2), 1. http://jasss.soc.surrey.ac.uk/6/2/1.html 
Barreteau, O., Bousquet, F., \& Attonaty, J.-M. (2001). Role-playing games for opening the black box of multi-agent systems: methods and lessons of its application to Senegal River Valley irrigated systems. Journal of Artificial Societies and Social Simulation, 4(2), 5. http://jasss.soc.surrey.ac.uk/4/2/5.html

Barreteau, O., Le Page, C., \& D’Aquino, P. (2003b). Role-playing games, models and negotiation processes. Journal of Artificial Societies and Social Simulation, 6(2), 10. http://jasss.soc.surrey.ac.uk/6/2/10.html

Berman, M., Nicolson, C., Kofinas, G., Tetlichi, J., \& Martin, S. (2004). Adaptation and sustainability in a small Arctic community: results of an agent-based simulation model. Arctic, 57(4), 401-414. https://doi.org/10.14430/arctic517

Bharwani, S., Besa, M. C., Taylor, R., Fischer, M. Devisscher, T., \& Kenfack, C. (2015). Identifying salient drivers of livelihood decision-making in the forest communities of Cameroon: adding value to social simulation models. Journal of Artificial Societies and Social Simulation, 18(1), 3. http://jasss.soc.surrey.ac.uk/18/1/3.html

Bommel, P., Bécu, N., Le Page, C., \& Bousquet, F. (2016). Cormas: an agent-based simulation platform for coupling human decisions with computerized dynamics. In T. Kaneda, H. Kanegae, Y. Toyoda, \& P. Rizzi (Eds.), Simulation and Gaming in the Network Society (pp. 387-410). Singapore: Springer. https://doi.org/10.1007/978-981-10-0575-6_27

Booch, G., Rumbaugh, J., \& Jacobson, I. (1997). UML Notation Guide, Version 1.1. Retrieved from www.omg.org/techprocess/meetings/schedule/Technology Adoptions.htm

Bousquet, F., \& Le Page, C. (2004). Multi-agent simulations and ecosystem management: a review. Ecological Modelling, 176, 313-332. https://doi.org/10.1016/j.ecolmodel.2004.01.011

Bousquet, F., Bakam, I., Proton, H., \& Le Page, C. (1998). Cormas: common-pool resources and multi-agent systems. In Tasks and Methods in Applied Artificial Intelligence (pp. 826-837). The 11th International Conference on Industrial and Engineering Applications of Artificial Intelligence and Expert Systems IEA-98-AIE Benicàssim, 1-4 June 1998, Castellón, Spain. https://doi.org/10.1007/3-540-64574-8 469

Bousquet, F., Barreteau, O., D’Aquino, P., Étienne, M., Boissau, S., Aubert, S., Le Page, C., Babin, D., \& Castella, J. C. (2002). Multi-agent systems and role games: collective learning processes for ecosystem management. In M. A. Janssen (Ed.), Complexity and Ecosystem Management - The Theory and Practice of Multi-Agent Systems (pp. 248-285). Cheltenham, UK: Edward Elgar.

Burton, V. J., \& Eggleton, P. (2016). Microhabitat heterogeneity enhances soil macrofauna and plant species diversity in an Ash - Field Maple woodland. European Journal of Soil Biology, 75, 97-106. https://doi.org/10.1016/j.ejsobi.2016.04.012

Campo, P. C., Mendoza, G. A., Guizol, P., Villanueva, T. R., \& Bousquet, F. (2009). Exploring management strategies for community-based forests using multi-agent systems: a case study in Palawan, Philippines. Journal of Environmental Management, 90, 3607-3615. https://doi.org/10.1016/j.jenvman.2009.06.016

Cundill, G., \& Fabricius, C. (2010). Monitoring the governance dimension of natural resource co-management. Ecology and Society, 15(1), 15. http://www.ecologyandsociety.org/vol15/iss1/art15/

Daré, W., Venot, J.-P., Le Page, C., \& Aduna, A. (2018). Problemshed or watershed? Participatory modeling towards IWRM in north Ghana. Water, 10, 721. https://doi.org/10.3390/w10060721

Drogoul, A., \& Ferber, J. (1994). Multi-agent simulation as a tool for studying emergent processes in societies. In N. Gilbert, \& J. Doran (Eds.), Simulating Societies: the computer simulation of social phenomena (pp. 127-142). London, UK: UCL Press.

Dumrongrojwatthana, P., Le Page, C., Gajaseni, N., \& Trébuil, G. (2011). Co-constructing an agent-based model to mediate land use conflict between herders and foresters in northern Thailand. Journal of Land Use Science, 6(2-3), 101-120. https://doi.org/10.1080/1747423X.2011.558596

Edwards, P., Sharma-Wallace, L., Wreford, A., Holt, L., Cradock-Henry, N. A., Flood, S., \& Velarde, S. J. (2019). Tools for adaptive governance for complex social-ecological systems: a review of role-playing-games as serious games at the community-policy interface. Environmental Research Letters, 14, 113002. https://doi.org/10.1088/17489326/ab4036

Étienne, M. (Ed). (2014). Companion Modelling: a participatory approach to support sustainable development. The Netherlands: Springer Netherlands.

Étienne, M., Le Page, C., \& Cohen, M. (2003). A step-by-step approach to building land management scenarios based on multiple viewpoints on multi-agent system simulations. Journal of Artificial Societies and Social Simulation, 6(2), 2. http://jasss.soc.surrey.ac.uk/6/2/2.html

Ferrand, N., Farolfi, S., Abrami, G., \& Du Toit, D. (2009). WAT-A-GAME: sharing water and policies in your own basin. In ISAGA 2009. The 40th Annual Conference of International Simulation and Gaming Association, 29 June-3 July 2009, Singapore, Singapore.

Folke, C., Carpenter, S. R., Walker, B., Scheffer, M., Chapin, T., \& Rockström, J. (2010). Resilience thinking: integrating resilience, adaptability and transformability. Ecology and Society, 15(4), 20. http://www.ecologyandsociety.org/vol15/iss4/art20/

Fraser, E. D. G., Dougill, A. J., Mabee, W. E., Reed, M., \& McAlpine, P. (2006). Bottom up and top down: analysis of participatory processes for sustainability indicator identification as a pathway to community empowerment and sustainable environmental management. Journal of Environmental Management, 78, 114-127. https://doi.org/10.1016/j.jenvman.2005.04.009

Gauli, K., \& Hauser, M. (2009). Pro-poor commercial management of non-timber forest products in Nepal's community forest user groups: factors for success. Mountain Research and Development, 29(4), 298-307. https://doi.org/10.1659/mrd.00051 
Gleizes, M.-P., Camps, V., Karageorgos, A., \& Di Marzo Serugendo, G. (2011). Agents and multi-agent systems. In G. Di Marzo Serugendo, M.-P. Gleizes, \& A. Karageorgos (Eds.), Self-organising Software: from natural to artificial adaptation, pp. 105-119. Berlin, Germany: Springer-Verlag.

Grimm, V., Berger, U., Bastiansen, F., Eliassen, S., Ginot, V., Giske, J., John, G.-C., Grand, T., Heinz, S. K., Huse, G., Huth, A., Jepsen, J. U., Jørgensen, C., Mooij, W. M., Müller, B., Pe'er, G., Piou, C., Railsback, S. F., Robbins, A. M., Robbins, M. M., Rossmanith, E., Rüger, N., Strand, E., Souissi, S., Stillman, R. A., Vabø, R., Visser U., \& DeAngelis, D. L. (2006). A standard protocol for describing individual-based and agent-based models. Ecological Modelling, 198, 115-126. https://doi.org/10.1016/j.ecolmodel.2006.04.023

Grimm, V., Berger, U., DeAngelis, D. L., Polhill, J. G., Giske, J., \& Railsback, S. F. (2010). The ODD protocol: a review and first update. Ecological Modelling, 221, 2760-2768. https://doi.org/10.1016/j.ecolmodel.2010.08.019

Herrero, P., Dedeurwaerdere, T., \& Osinski, A. (2019). Design features for social learning in transformative transdisciplinary research. Sustainability Science, 14, 751-769. https://doi.org/10.1007/s11625-018-0641-7

Hess, C., \& Ostrom, E. (2003). Ideas, Artifacts, and Facilities: Information as a Common-Pool Resource. Law and Contemporary Problems, 66(1/2), 111-145. www.jstor.org/stable/20059174

Hurlbert, M., \& Gupta, J. (2015). The split ladder of participation: a diagnostic, strategic, and evaluation tool to assess when participation is necessary. Environmental Science \& Policy, 50, 100-113. https://doi.org/10.1016/j.envsci.2015.01.011

Janssen, M. A., \& Ostrom, E. (2006). Empirically based, agent-based models. Ecology and Society, $11(2), 37$. http://www.ecologyandsociety.org/vol11/iss2/art37

Khadka, C., \& Vacik, H. (2012). Comparing a top-down and bottom-up approach in the identification of criteria and indicators for sustainable community forest management in Nepal. Forestry, 85(1), 145-158. https://doi.org/10.1093/forestry/cpr068

Laurance, W. F. (2008). Theory meets reality: how habitat fragmentation research has transcended island biogeographic theory. Biological Conservation, 141, 1731-1744. https://doi.org/10.1016/j.biocon.2008.05.011

Le, Q. B., Park, S. J., Vlek, P. L. G., \& Cremers, A. B. (2008). Land-use dynamic simulator (LUDAS): a multi-agent system model for simulating spatio-temporal dynamics of coupled human-landscape system. I. Structure and theoretical specification. Ecological Informatics, 3(2), 135-153. https://doi.org/10.1016/j.ecoinf.2008.04.003

Le Page, C., Dray, A., Perez, P., \& Garcia, C. (2016). Exploring how knowledge and communication influence natural resources management with ReHab. Simulation \& Gaming, 47(2), 257-284. https://doi.org/10.1177/1046878116632900

Le Page, C., \& Perrotton, A. (2018). KILT: A modelling approach based on participatory agent-based simulation of stylized socio-ecosystems to stimulate social learning with local stakeholders. In G. Dimuro, \& L. Antunes (Eds.), Multi-Agent Based Simulation XVIII, International Workshop, MABS 2017 (pp. 31-44). Springer, Cham. https://doi.org/10.1007/978-3-319-91587-6_11

Lippe, M., Bithell, M., Gotts, N., Natalini, D., Barbrook-Johnson, P., Giupponi, C., Hallier, M., Hofstede, G. J., Le Page, C., Matthews, R. B., Schlüter, M., Smith, P., Teglio, A. \& Thellmann, K. (2019). Using agent-based modelling to simulate social-ecological systems across scales. Geolnformatica, 23(2), 269-298. https://doi.org/10.1007/s10707-01800337-8

MacArthur, R. H., \& Wilson, E. O. (2001). The Theory of Island Biogeography. USA: Princeton University Press.

Myllyviita, T., Hujala, T., Kangas, A., Eyvindson, K., Sironen, S., Leskinen, P., \& Kurttila, M. (2014). Mixing methods assessment of potential benefits for natural resources planning. Scandinavian Journal of Forest Research, 29(Supplement 1), 20-29. https://doi.org/10.1080/02827581.2013.859297

Nantasen, N., Panyain, T., Thanatheerabunjong, B., Klinchan, P., Maruean, I., Nongchang, P., Wichalek, H., Pila, T, Runnawut, K., \& Wichalek, J. (2005). Social collaboration for forest and water resource management at Lainan Sub-district, Wiang Sa District, Nan Province. Research Report for Locality, Thailand Research Fund. [In Thai].

National Statistical Office. (2020). National statistical report. [In Thai]. Retrieved from http://statbbi.nso.go.th/staticreport/page/sector/th/index.aspx

Nayak, P. K., \& Berkes, F. (2008). Politics of co-optation: community forest management versus joint forest management in Orissa, India. Environmental Management, 41, 707-718. https://doi.org/10.1007/s00267-008-9088-4

Ostrom, E. (2009). A general framework for analyzing sustainability of social-ecological systems. Science, 325(5939), 419422. https://doi.org/10.1126/science.1172133

Promburom, P., \& Bommel, P. (2005). Participatory multi-agent system modeling for collective watershed management in northern Thailand: a Companion Modeling method. In V. Kachitvichyanukul, U. Purintrapiban, \& P. Utayopas (Eds.), Proceedings of the 2005 International Conference on Simulation \& Modeling (pp. 453-460), 17-19 January 2005, Bangkok, Thailand.

Promburom, P. (2010). Companion Modelling and Watershed Management in Northern Thailand: the importance of local networks. Doctoral Thesis, Université Claude Bernard Lyon 1, France.

Purnomo, H., \& Guizol, P. (2006). Simulating forest plantation co-management with a multi-agent system. Mathematical and Computer Modelling, 44, 535-552. https://doi.org/10.1016/j.mcm.2006.01.009

Robinson, D. T., Brown, D. G., Parker, D. C., Schreinemachers, P., Janssen, M. A., Huigen, M., Wittmer, H., Gotts, N., Promburom, P., Irwin, E., Berger, T., Gatzweiler, F., \& Barnaud, C. (2007). Comparison of empirical methods, for building agent-based models in land use science. Journal of Land Use Science, 2(1), 31-55. https://doi.org/10.1080/17474230701201349 
Ruankaew, N., Le Page, C., Dumrongrojwatthana, P., Barnaud, C., Gajaseni, N., Van Paassen, A., \& Trébuil, G. (2010). Companion Modelling for integrated renewable resource management: a new collaborative approach to create common values for sustainable development. International Journal of Sustainable Development \& World Ecology, 17(1), 15-23. https://doi.org/10.1080/13504500903481474

Salam, M. D. A., Noguchi, T., \& Pothitan, R. (2006). Community forest management in Thailand: current situation and dynamics in the context of sustainable development. New Forests, 31, 273-291. https://doi.org/10.1007/s11056005-7483-8

Schultz, L., Duit, A., \& Folke, C. (2011). Participation, adaptive co-management, and management performance in the world network of biosphere reserves. World Development, 39(4), 662-671. https://doi.org/10.1016/j.worlddev.2010.09.014

Schulze, J., Müller, B., Groeneveld, J., \& Grimm, V. (2017). Agent-based modelling of social-ecological systems: achievements, challenges, and a way forward. Journal of Artificial Societies and Social Simulation, 20(2), 8. http://jasss.soc.surrey.ac.uk/20/2/8.html

Simon, C., \& Étienne, M. (2010). A companion modelling approach applied to forest management planning. Environmental Modelling \& Software, 25(11), 1371-1384. https://doi.org/10.1016/j.envsoft.2009.09.004

Sun, Z., \& Müller, D. (2013). A framework for modelling payments for ecosystem services with agent-based models, Bayesian belief networks and opinion dynamics models. Environmental Modelling \& Software, 45, 15-28. https://doi.org/10.1016/j.envsoft.2012.06.007

Thavikulwat, P. (2009). Social choice in a computer-assisted simulation. Simulation \& Gaming, 40(4), 488-512. https://doi.org/10.1177/1046878109335921

Trébuil, G., Bousquet, F., Ekasingh, B., Baron, C., \& Le Page, C. (2005). A multi-agent model linked to a GIS to explore the relationship between crop diversification and the risk of land degradation in northern Thailand highlands. In $\mathrm{F}$. Bousquet, G. Trébuil, \& B. Hardy (Eds.), Companion Modeling and Multi-Agent Systems for Integrated Natural Resource Management in Asia (pp. 167-190). Los Baños, The Philippines: International Rice Research Institute.

Van Bruggen, A., Nikolic, I., \& Kwakkel, J. (2019). Modeling with stakeholders for transformative change. Sustainability, 11(3), 825. https://doi.org/10.3390/su11030825

Van Noordwijk, M. (2002). Scaling trade-offs between crop productivity, carbon stocks and biodiversity in shifting cultivation landscape mosaics: the FALLOW model. Ecological Modelling, 149(1-2), 113-126. https://doi.org/10.1016/S03043800(01)00518-X

Villamor, G. B., Le, Q. B., Djanibekov, U., Van Noordwijk, M., \& Vlek, P. L. G. (2014). Biodiversity in rubber agroforests, carbon emissions, and rural livelihoods: an agent-based model of land-use dynamics in lowland Sumatra. Environmental Modelling \& Software, 61, 151-165. https://doi.org/10.1016/j.envsoft.2014.07.013

Whitfield, S., Geist, H. J., \& loris, A. A. R. (2011). Deliberative assessment in complex socioecological systems: recommendations for environmental assessment in drylands. Environmental Monitoring and Assessment, 183, 465483. https://doi.org/10.1007/s10661-011-1933-x

Williams, B. K. (2011). Adaptive management of natural resources-framework and issues. Journal of Environmental Management, 92, 1346-1353. https://doi.org/10.1016/j.jenvman.2010.10.041

Wimolsakcharoen, W., Dumrongrojwatthana, P., \& Trébuil, G. (2020). Production of non-timber forest products (NTFPs) and diversity of harvesters' practices and decision-making processes in northern Thailand community forests. Bois et Forêts des Tropiques, 343, 39-52. https://doi.org/10.19182/bft2020.343.a31845

Wise, S., \& Crooks, A. T. (2012). Agent-based modeling for community resource management: acequia-based agriculture. Computers, Environment and Urban Systems, 36, 562-572. https://doi.org/10.1016/j.compenvurbsys.2012.08.004 